\title{
ALFABETIZAÇÃO MIDIÁTICA EM PERSPECTIVA MULTIDISCIPLINAR NA EDUCAÇÃO INFANTIL PARA FORMAÇÃO CIDADÃ: UM OLHAR SOBRE AS PANDEMIAS DO CONSUMO INFANTIL E DA COVID-19
}

\section{DIEGO HENRIQUE DAMASCENO COÊLHO', CAMILA CORREA BRAGA ${ }^{2}$, FLAVIO ALMEIDA RIBEIRO ${ }^{3}$, ANDRÉIA ALMEIDA MENDES ${ }^{4}$, HUMBERTO VINÍCIO ALTINO FILHO}

\begin{abstract}
${ }^{1}$ Mestre em Justiça Administrativa (PPGJA), pela Universidade Federal Fluminense (UFF); MBA em Gestão Pública (UCAM); Especialista em Processo e Direito do Trabalho com Habilitação no Magistério Superior (FDDJ); Especialista em Pedagogia e Docência em Educação Profissional e Tecnológica (UCAM); Bacharel em Direito. diegocoelho.contato@gmail.com

${ }^{2}$ Mestra em Justiça Administrativa (PPGJA), pela Universidade Federal Fluminense (UFF). Professora no Centro Universitário UNIFACIG. camilabragacorrea@gmail.com

3 Mestre em Justiça Administrativa (PPGJA), pela Universidade Federal Fluminense (UFF). flavioribeiro10@gmail.com.

4 Doutora em Linguística pela Universidade Federal de Minas Gerais (UFMG), Coordenadora de Pesquisa e Extensão e professora do Centro Universitário UNIFACIG. andreialetras@ yahoo.com.b

${ }^{5}$ Mestre em Educação Matemática pela UFOP, Especialista em Estatística pela FATESF, Licenciado em Matemática pela FACIG. Professor e Analista Educacional no Centro Universitário UNIFACIG. humbertovinicio@hotmail.com
\end{abstract}

\section{RESUMO}

A expansão dos meios de comunicação, a ubiquidade promovida pela conectividade em dispositivos tecnológicos e o acesso à informação, por via das mídias, representam novas formas de linguagem e de expressão no século XXI. Desse modo, a alfabetização midiática desponta como área da pedagogia e da didática capaz de habilitar os indivíduos para lidar com a mídia com confiança, autodeterminação, criatividade e criticidade, transpondo a mera operação de dispositivos, mas podendo ser aprendida da mesma maneira que as técnicas culturais clássicas de leitura, escrita e aritmética, tendo por objetivo final a educação para a mídia, a qual já pode ser iniciada como parte da educação nos primeiros estágios escolares e que, per se, uma modalidade pluripotente e capaz de colaborar com a educação à distância, sobretudo em contextos disruptivos ao modelo tradicional educativo, tal como durante a pandemia do COVID-19. Assim, a presente pesquisa foi preparada e desenvolvida, utilizando o método quantitativo, com o escopo de aprofundamento a respeito da aprendizagem midiática, traçando a sua historiografia, apresentando os seus conceitos fundamentais e observando as experiências em perspectiva comparada, quando produzidas em outros países, bem como demonstrando a sua usabilidade como possível mecanismo integrante do processo de alfabetização de crianças, na grade curricular brasileira, face à necessidade de promover a Educação através de abordagens mais contextualizadas ao meio digital, como forma de promoção da autonomia cidadã de aprendizagem com a utilização de ferramentas eletrônicas e Tecnologias da Informação e da Comunicação.

Palavras-Chave: Aprendizagem Midiática; Consumo Infantil; Tecnologias; Pedagogia Didática; COVID-19. 


\title{
THE MEDIA LITERACY, FROM A MULTIDISCIPLINARY PERSPECTIVE IN CHILDHOOD EDUCATION FOR CITIZENSHIP FORMATION: A VIEW ON THE PANDEMIAS OF CHILD CONSUMPTION AND COVID-19
}

\begin{abstract}
The expansion of the media, the ubiquity promoted by connectivity in technological devices and access to information, through the media, represent new forms of language and expression in the 21st century. In this way, media literacy emerges as an area of pedagogy and didactics capable of enabling individuals to deal with the media with confidence, self-determination, creativity and criticality, transposing the mere operation of devices, but can be learned in the same way as the traditional techniques of reading, writing and arithmetic calculations, with the ultimate goal of education for the media, which can already be started as part of education in the primary school and which, per $s e$, can be a pluripotent modality of learning, as well as capable of collaborating with distance education, especially in disruptive contexts to the traditional educational model, such as during the COVID-19 pandemic. Thus, the present research was prepared and developed, using a qualitative methodology, with the scope of deepening about media learning, tracing its historiography, presenting its fundamental concepts and observing the experiences in a comparative perspective, when produced in other countries, as well as demonstrating its usability as a possible integrating mechanism of the children's literacy process, in the Brazilian curriculum subjects, given the need to promote Education through more contextualized approaches to the digital environment, as a way of promoting citizen learning autonomy with the use of electronic tools and Technologies of Information and Communication.
\end{abstract}

Keywords: Media Literacy; Child as Consumers; Technologies; Didatic Pedagogy; COVID-19.

\section{INTRODUÇÃO}

A proliferação das recentes tecnologias digitais possibilitou novas modalidades de publicidade e marketing virtuais vinculadas aos meios de comunicação em massa através das mídias, inserindo suas propagandas de incentivo ao consumo nos mais variados meios de comunicação, informação, lazer e cultura (REIHER; ACUFF, 2008, p. 128). As técnicas empregadas de modo estruturalmente subjetivo na linguagem publicitária são capazes de produzir efeitos sensoriais e emocionais, traduzidas em questões psicossociais do desenvolvimento humano e figurando no público infantil o grupo mais suscetível a ser ludibriado pela linguagem publicitária, imperativa e em 
discurso de autoridade, num contexto de propensão à aceitação de influências externas e ideias, não distinguindo a persuasão como verdadeira ou falsa (MCNEAL, 1992, p. 37).

Logo, as crianças estão rapidamente se tornando um dos grupos mais visados nas indústrias de publicidade e marketing, pois influenciam diretamente na forma como os pais gastam com elas, ao mesmo tempo em que geram fidelidade às marcas e determinam os hábitos de consumo que as seguirão por toda a vida (KOTLER et al, 2016, p. 47). Isso não afeta apenas o desenvolvimento cognitivo geral de uma criança, como também começa a interferir na maneira como elas se percebem e interagem socialmente, muitas vezes crescendo focadas na importância de itens do materialismo e se convencendo da constante insuficiência do que possuem, resultando em uma demanda constante por mais quantidades e novidades de produtos e bens consumíveis (GUNTER, 2015, p. 21), sem desenvolverem práticas competências e habilidades de conviverem com tais estímulos de modo crítico, realista e em segurança.

O Estado de Direito no qual se funda a sociedade de consumo, pelo viés da amostra representada por crianças, permite observar o retrato de muitos dos fenômenos sociais ensejados pelas transformações tecnológicas, atuando diretamente na forma como indivíduos, na infância, ocupam o espaço onde se encontram e convivem em família, na escola e com os demais personagens do cotidiano, de modo a pautar seus desejos a partir dessas influências e daquelas trazidas pela publicidade, propaganda e marketing em ambientes virtuais, atrelados a jogos, animações, vídeos e mídias sociais, tendo em vista os longos períodos a que ficam expostas.

A história do termo "alfabetização midiática", em seu meio de mediação e aplicação, a "educação midiática", é caracterizada por correntes e ciclos temporariamente dominantes, mas não mutuamente exclusivos. Tais ciclos costumam representar, também, a expressão de um contexto sociopolítico, tal como ocorrido quando de seu estabelecimento, numa fase de cunho mais liberal na Europa, marcadamente no final da década de 1960, quando a "alfabetização midiática" passou a ser compreendida, segundo Hoffmann (2003, p. 29), como forma de fazer a população estar presente em todos os lugares, inclusive na produção de mídia.

Nas publicações de Enzensberger (2003, p 49), sobre a democratização da mídia experimentada no final da década de 1960, o termo alfabetização midiática recebe uma mudança de significado, numa fase em que a mídia era frequentemente utilizada como 
uma forma ameaça, nos anos 50 e 60. Criando uma atitude reticente, cética ou negativa em relação à televisão e às novas mídias em geral, baseava-se na suposição de muitos educadores de que o livro era o meio mais valioso (HOFFMANN, 2003, p. 39). Pretendia-se, portanto, preservar os antigos valores culturais por meio de medidas educacionais. A alfabetização midiática foi entendida, nesse contexto, como a capacidade de distinguir o conteúdo valioso do conteúdo inferior e selecionar os conteúdos certos e benéficos para serem ensinados (HÜBNER, 2015, p.21).

Através da pedagogia orientada para a ação e do trabalho cultural nos anos $70 \mathrm{e}$ 80, a mídia foi percebida em seu potencial criativo para a socialização educacional, com base nos princípios orientadores dominados pela competência comunicativa, o mundo acessível por tecnologias, a construção da vida cotidiana, a experiência autêntica, o aprendizado ativo e, acima de tudo, a competência de ação e a alfabetização midiática. Nesse sentido, a aprendizagem baseada na ação, no campo da realidade social, e a realidade devem ser apropriadas, moldadas e transformadas na combinação de reflexão e ação (HABERMAS, 1987, p 187).

Segundo Vollbrecht (2001, p. 41), a alfabetização midiática não representa somente a aquisição de certas habilidades, tais como o uso de um programa de computador específico; mas, além disso, representa a possibilidade de aprender sobre qualquer programa, em perspectiva geral. Vollbrecht (2001), portanto, entende a alfabetização midiática como a construção de estruturas cognitivas que permitem às pessoas a utilização das mídias como quiserem (criativamente) e não se comprometendo com uma ação específica ou preordenada.

A aprendizagem midiática tem ganhado espaço nas discussões pedagógicas de países nos quais o acesso a produtos digitais é mais amplificado do que no Brasil, sendo esses produtos empregados nos sistemas de Ensino, tornando-os progressivamente indissociáveis da Educação na Sociedade da Informação. Tais conceitos têm suas usabilidades ampliadas, quando sistemas e sociedades enfrentam contextos disruptivos, os quais são capazes de alterar estruturas tradicionais, especialmente nos setores da Educação. O cenário decorrente da pandemia do COVID-19 é um exemplo de como políticas de gestão de crise, tais como o fechamento de instituições de ensino, em escala global, e o isolamento social, realocaram os sistemas educacionais presenciais para o ambiente virtual, da educação infantil (0 a 5 anos), à pós-graduação. 
Tais alterações representam desafios tanto para gestores e professores, quanto para dos alunos, sobretudo os que se encontram cronologicamente na infância, e pedagogicamente nas fases de alfabetização e letramento, quando a estruturação de capacidades cognitivas associadas à leitura e à intepretação de textos e sinais é bastante relevante para a utilização de equipamentos de Tecnologia da Informação e Comunicação, a aprendizagem em ambiente virtual e a convivência social e crítica na Internet, como um desdobramento para-material do mundo, mas com possibilidade de impactos reais e profundos para indivíduos, famílias e a coletividade.

Desse modo, a presente pesquisa foi preparada e desenvolvida com o escopo de aprofundamento a respeito da aprendizagem midiática, traçando a sua historiografia, apresentando os seus conceitos fundamentais e observando as experiências em perspectiva comparada, quando produzidas em outros países, bem como demonstrando a sua usabilidade como possível mecanismo integrante do processo de alfabetização de crianças, na grade curricular brasileira. $\mathrm{O}$ objetivo principal é produzir um estudo aprofundado a partir das informações obtidas por meio da análise qualitativa, através dos métodos hipotético-dedutivo, comparativo e investigativo, utilizando a revisão bibliográfica e doutrinária de fontes literárias nacionais e internacionais, bem como embasando as proposições em dados quantitativos, os quais possibilitam demonstrar a correlação entre o consumo infantil e a necessidade de promover a Educação através de abordagens mais contextualizadas ao meio digital, como forma de promoção cidadã, tendo por pano de fundo as normas de proteção, privacidade e igualdade, como garantias fundamentais a serem discutidas no contexto da Revolução 4.0 e sobre os desdobramentos da COVID-19. Da mesma maneira, serão trazidas a comento outras informações advindas de árvores científicas, em multidisciplinariedade, tais como as da Pedagogia, Direito, Sociologia, Economia, Psicologia, Publicidade e Propaganda, Tecnologias da Informação e Comunicação (TICs) e Didática, dentre outras, num marco temporal compreendendo o advento da internet e dos mais recentes bens de consumo digitais nos ambientes domésticos, mormente entre os anos 2000 a 2018.

Ao final, o projeto de pesquisa está estruturado na busca pelo conhecimento, localização e interpretação de temas atuais e polêmicos, questões controversas e ainda pouco debatidas no ambiente educacional e pedagógico do Brasil, promovendo a apresentação de novos pontos de vista, no intuito de produzir uma investigação tão 
detalhada e meticulosa quanto inédita e contributiva, além de humildemente colaborar com informações capazes de fazer o leitor repensar as implicações e responsabilidades da formação de crianças dentro da sociedade de consumo e face às tecnologias, sob o prisma da aprendizagem midiática, superando as limitações do ambiente escolar, mas compreendendo os fenômenos educativos através de todo e qualquer estímulo exposto às crianças, como forma de pensar responsavelmente as novas necessidades curriculares, na construção de um pensamento cidadão e no passo das necessidades contemporâneas.

\section{CONCEITOS MODERNOS SOBRE APRENDIZAGEM MIDIÁTICA COM O ADVENTO DA INTERNET}

Desde os anos de 1990, a alfabetização midiática, segundo Potter (2003, p. 47), tornou-se particularmente importante; podendo o termo ser subdividido em quatro dimensões: (I) Crítica da mídia; (II) Estudos de Mídia; (III) Uso de mídia e; (IV)Media Design.

A dimensão de crítica da mídia deve analisar e captar adequadamente os processos sociais problemáticos. Assim, toda pessoa deve ser reflexivamente capaz de aplicar o conhecimento analítico a si mesma e às suas ações. A sub-dimensão ética da crítica de mídia refere-se à capacidade de levar em conta as consequências sociais do desenvolvimento da mídia (HOFFMANN, 2003, p.40).

A partir dos estudos de mídia como meios de comunicação audiovisuais, é possível compreender os sistemas de mídia atuais, partindo do conhecimento clássico, o qual produzirá a sub-dimensão instrumental-qualificativa, traduzida como a capacidade de operar novos dispositivos (HÜBNER, 2015, p. 31). Os dois aspectos, da crítica de mídia e dos estudos de mídia, incluem a sub-dimensão da mediação ou orientação, pelo conjunto de ações possíveis dos indivíduos, face à utilização dos mecanismos mediáticos de comunicação.

O design de mídia fornece a diferenciação entre mudanças e desenvolvimentos do sistema de mídia, face às variantes estéticas e ou criativas, as quais transcendem os limites de rotinas de comunicação diárias, do nível social ao supra individual (GAPSKI, 2001, p. 33). No contexto da Sociedade da Informação, tal discurso envolve todas as 
questões econômicas, técnicas, sociais, culturais e estéticas; por isso, pode e deve ser constantemente atualizado.

O uso ativo dos meios de comunicação deve emergir das faculdades críticas, que podem ser usadas para selecionar diferentes ofertas de mídia (POTTER, 2016, p 130). Em suma: o próprio trabalho ativo com um meio de comunicação em mídia possibilita seu uso crítico no cotidiano profissional e privado (HABERMAS, 1987, p. 82).

Dessa forma, a competência em mídia também estaria relacionada com disciplinas-chave, alocadas em três blocos de construção complementares, compreendidas em ligação com as Tecnologias da Informação e da Comunicação (TIC's), sendo elas: (I) competência para o manuseio e uso da tecnologia; (II) competência para a concepção de sistemas sociotécnicos com a ajuda da tecnologia e; (III) competência para a crítica especializada da tecnologia (POTTER, 2003, p. 58)

Bernward Hoffmann (2003, p. 39), também subdivide a literacia midiática em quatro outros aspectos: a referência pessoal, prima facie, descreve a percepção sensorialmente afetiva e a experiência das influências midiáticas no indivíduo; sua maturidade em relação à mídia deve ser projetada para entender o design e a condicionalidade da mídia, bem como para compreendê-la.

Como segunda competência-chave na atual sociedade da informação, Hoffmann (2003, p. 41) representa a referência social: a alfabetização midiática não deve ser projetada subjetivamente no indivíduo, mas deve ser vista no contexto da sociedade e de seus grupos (econômicos, sociais, culturais).

A inclusão de informações da mídia e, portanto, empregada como uma "linguagem receptiva"”, representa o terceiro aspecto. A mídia é um importante sistema de referência social para os seres humanos, no qual a compreensão do mundo pode ser simplificada audiovisualmente. Portanto, é necessário estar consciente quanto à diversidade da oferta de mídia, para torná-la utilizável. Isso é alcançado, como quarto aspecto, pelo sujeito da comunicação através da participação ativa no cotidiano midiático, utilizando-a como uma ferramenta para compreender os seus próprios interesses sociais.

\footnotetext{
${ }^{1}$ Linguagem receptiva é a capacidade de entender palavras e linguagem. Envolve a obtenção de informações e significados da rotina, informações visuais no ambiente, sons e palavras, conceitos como tamanho, forma, cores e tempo, gramática e informações escritas e imagens.
} 
Numa análise de mais de uma centena de definições de alfabetização midiática, Gapski (2001, p. 21) mostra que, nas explicações da terminologia examinada, são normalmente diferenciadas as dimensões ou níveis diferentes para tornar um conceito complexo de modo descritível. A aprendizagem midiática é uma disciplina relativamente nova, destinada a ensinar as pessoas a entender e usar a mídia em proveito próprio, sendo cada vez mais reconhecida por governos e organizações internacionais, como a União Europeia e a Organização Mundial de Saúde, como uma ferramenta chave para ajudar as crianças a entenderem e lidarem com o complexo ambiente midiático de hoje (POTTER, 2016, p. 64). Os programas de alfabetização midiática baseiam-se na necessidade de fazer com que as crianças se envolvam na mídia ao invés de apenas consumi-la (TYNER, 2009, p. 35).

A aprendizagem midiática permite que as pessoas acessem, analisem, interpretem e questionem as mensagens da mídia através do uso de habilidades integradas. Existem sete habilidades-chave, que são: análise, avaliação, agrupamento, indução, dedução, síntese e abstração (POTTER, 2004, p. 72). A disciplina inclui a capacidade de reconhecer componentes significativos, avaliar o conteúdo e reconhecer semelhanças e diferenças (ibidem, 2004, 87). Ensina as pessoas a questionar o que veem na mídia e a tomar consciência das mensagens subliminares daquilo que não está sendo anunciado diretamente. A alfabetização midiática diz respeito à proteção daqueles que são vulneráveis a mensagens de mídia mal interpretadas. Promove também a conscientização das oportunidades e uma compreensão positiva da mídia por meio da comunicação e da aprendizagem. Os indivíduos são encorajados a se envolverem com a mídia para aprimorar seu conhecimento do ambiente da mídia (BURN, DURRAN, 2007, p. 46).

Desta forma, Ciurel (2016, p. 9-20) descreve cinco princípios fundamentais da aprendizagem midiática. Em primeiro lugar, "todas as mensagens de mídia são construídas", isso significa que as mensagens mostram o que elas querem que as pessoas vejam e excluem certas coisas para transmitir ideias da maneira que elas querem que as pessoas as recebam. Em segundo lugar, "as mensagens de mídia são construídas usando uma linguagem criativa com suas próprias regras e códigos", de modo que as mensagens de mídia usam seus códigos técnicos e culturais genéricos para melhorar a mensagem e se conectar com seu público. Em terceiro lugar, "diferentes 
membros da audiência interpretam as mensagens da mídia de maneira diferente", o que significa que nem todas as pessoas interpretam as mensagens da forma como foram planejadas, algumas pessoas as consideram verdadeiras, enquanto outras questionam a mensagem e são mais críticas. Em quarto lugar, "mensagens de mídia contêm valor incorporado e pontos de vista", por via de massagens diretas e facilmente identificadas, bem como mensagens indiretas que não são tão perceptíveis para o público. Por fim, "a maioria das mensagens de mídia é organizada para obter lucro ou poder", o que significa que os lucros são o principal objetivo das empresas de mídia, com informações e entretenimento sendo considerações secundárias.

\subsection{Métodos e objetivos da alfabetização midiática na fase escolar}

De acordo com Vollbrecht (2001, p. 57), a alfabetização midiática também é entendida como uma competência ativa, de modo a não considerar o ambiente no qual ocorrem os fenômenos comunicativos como único centro da construção do conhecimento. No planejamento educacional, a alfabetização em mídias tem importância como ferramenta de cognição e interpretação, além de mecanismo de socialização em sala de aula e no fazer pedagógico, cuja instalação e seleção adequadas dos temas são parte integrante do planejamento de aulas.

O desenvolvimento do saber-fazer crítico traz consigo objetivos específicos de aprendizagem, os quais representam precedência na organização da prática docente da alfabetização midiática (HÜBNER, 2015, p. 94), visando o desenvolvimento de práticas e competências que alicercem os conhecimentos dos alfabetizandos para: (I) reconhecer a interação de mecanismos de mídia diferenciados; (II) integrar diferentes experiências midiáticas no próprio estilo de vida socialmente compatível; (III) refletir teoricamente sobre possibilidades e efeitos de ofertas midiáticas e classificá-las em contextos de vida. Tais níveis de competência são capazes de estimular os alunos a se envolverem com as mídias de forma independente, para começarem a refletir sobre tarefas mais complexas relacionadas à base de ofertas em mídias diferentes, bem como reconhecerem o papel dos meios de comunicação como fator econômico e elemento indispensável, constitutivo da sociedade moderna (HOFFMANN, 2003, p. 69) 
A operacionalização do conceito de alfabetização midiática tem profunda relação com a produção audiovisual, seguindo um modelo tríplice, o qual contempla, em primeiro lugar, a capacidade de comunicação ativa, por meio da aprendizagem e aplicação de possibilidades expressivas e criativas específicas e métodos jornalísticos. A "capacidade de comunicação ativa" com os meios audiovisuais, desde o planejamento e pesquisa, passando pela produção e formulação de conteúdo, até a capacidade de distribuir seus próprios produtos audiovisuais (VOLLBRECHT, 2001, p. 85).

Em seguida, elenca-se o "conhecimento das condições técnicas e organizacionais", traduzidas pela capacidade de lidar com as condições técnicas ( a exemplo: câmera, som, luz, edição, dublagem, transmissão de contribuições) e com as condições organizacionais, desde a fixação do conteúdo por escrito até as relações públicas e de distribuição de seus próprios produtos de mídia, de como a conhecer a cadeia produtiva e a mão-de-obra empregada na sequência da cadeia produtiva em mídias (VOLLBRECHT, 2001, p. 85).

Por fim, a "recepção competente", que pode ser compreendida como a sensibilização da própria percepção, mediante a capacidade de filtragem e análise competente da informação audiovisual, com a intenção de interpretação crítica e emocionalmente distante, quando o receptor já detém conhecimento de formatos e gêneros de produtos em mídia, sendo também capaz de discernir entre as limitações da aplicação no plano da realidade, face ao discurso propagandista e tendencialmente megalomaníaco da palavra plástica (HÜBNER, 2015, p. 97).

A alfabetização midiática, na perspectiva de Garski (2001, p. 76), já não representa apenas um termo exclusivo da discussão midiática-educacional, mas um constructo social com determinadas funções na sociedade midiática, que ultrapassa a linguagem didática e transpõem a persuasão, por vezes. No jogo de discursos políticos, jurídicos, educacionais, técnicos ou econômicos, dependendo do ator e do contexto, prevalece um entendimento diferente da competência em mídias (HABERMAS, 1987, p. 136).

A esse respeito, é possível traçar diferentes discursos de alfabetização midiática; alguns dos quais se interpenetram ou se referem, nos quais os termos empregados são moldados, adaptados e contidos. Dependendo do contexto, o termo preenche as outras funções de conexão comunicativa. Posicionar a alfabetização midiática como um 
conceito-chave na sociedade do conhecimento; entretanto, significa refletir os limites da liberdade, considerando tanto o autodesenvolvimento da consciência crítica em aplicação cidadã, quanto a verificação da manipulação e dos discursos de autoridade para convencimento de opiniões em massa.

\subsection{Alfabetização midiática como disciplina e como pedagogia: profissionalização e cidadania}

As habilidades de alfabetização permitem o desenvolvimento do indivíduo perante a vida, a liberdade e a busca da felicidade no século XXI (BOURDIEU, 1998, p. 41). Alfabetização midiática é alfabetização também. Todavia, o sistema educacional brasileiro negligenciou por muito tempo incorporá-la como disciplina e pedagogia, na aquisição e no discernimento do conhecimento sobre conteúdos. Desse modo, é possível discriminar as falhas na estrutura educacional e da pedagogia da alfabetização midiática. Enquanto a primeira versa sobre vontade política, projetos de governo e diálogos com instituições internacionais de fiscalização da educação, como a Organização das Nações Unidas para a Educação, a Ciência e a Cultura (UNESCO), a pedagogia é fruto dos esforços de educadores e dos filósofos e teóricos da educação, no escopo de aprimorar os construtos didáticos das disciplinas curriculares voltadas para a formação de cidadãos habilitados, também para o exercício profissional no mercado de trabalho.

A tecnologia, altamente acessível na atualidade, contrasta com a alfabetização. Tradicionalmente, as escolas têm enfatizado a transmissão do conhecimento de conteúdo dos professores, enquanto o ensino de habilidades de processamento de informações e de gerenciamento de projetos era incidental e não bem definido (GAPSKI, 2001, p. 157). Com o conteúdo sendo tão prontamente disponível hoje, as habilidades de aprendizagem são cada vez mais importantes e precisam ser formalmente ensinadas. Assim, os professores estão agora sendo encorajados a mudar de "sábio no palco" para "guia do lado" face aos alunos, para que esses últimos possam descobrir como aprender e o que aprender (BURN, 2007, p. 65).

Mas, para tornar a alfabetização midiática acessível a milhões, ela deve ser apresentada de uma maneira que funcione para milhões. A alfabetização midiática pode ser compreendida como uma "disciplina" ou como uma "pedagogia", sem a criação de 
uma dicotomia sobre ambos (HOFFMANN, 2003, p. 49). Afinal, como campo de estudo disciplinar, reflete a pedagogia em movimento, proporcionando a observação de características especiais, sobreposições, oportunidades e cuidados envolvidos em cada arena (BOURDIEU, 1992, p. 209).

Sob o prisma da aprendizagem midiática como disciplina, têm-se base o processo de alfabetização, pelo qual é preciso aprender sobre como os sistemas de mídia operam. Os sistemas de mídia podem ser sistematicamente identificados e analisados (daí os conceitos centrais de alfabetização midiática) e a exploração sistemática de um sistema no trabalho é a característica fundamental de uma disciplina. A maior cautela na difusão do estudo da alfabetização midiática como disciplina é estrutural, pois as escolas e universidades são divididas em silos de conhecimento optando, muitas vezes, pelo pragmatismo ao estudo interdisciplinar. A alfabetização midiática, como disciplina, exige "pensamento sistêmico" e estudo interdisciplinar. É um campo do século XXI com o qual as estruturas das disciplinas pragmáticas normalmente não conseguem diálogos profundos, tornando a busca pela alfabetização midiática um desafio.

Como pedagogia, a alfabetização midiática pretende viabilizar o ensino e o entendimento sobre a mídia, como duas habilidades diferentes. Os fundamentos da alfabetização midiática fornecem uma estrutura e uma estratégia de ensino/aprendizagem aplicáveis na escola e fora da escola, 24 horas por dia, sete dias por semana (HOFFMANN, 2003, p. 56 - 89). Utilizar a os conceitos da aprendizagem midiática funciona como estratégia para ajudar as pessoas a adquirir conhecimento de conteúdo e a discernir melhor as mensagens recebidas, de forma a habilitar os indivíduos a aprenderem de modo autodidatico, individualmente e ao longo da vida, também podendo auxiliar no ensino e no compartilhamento de seus conhecimentos com os demais (HÜBNER, 2015, p. 66). A alfabetização midiática está enraizada em um processo de investigação e essa é uma pedagogia fundamental e uma habilidade internalizada que faz sentido na atual cultura de informação pesada. Ensinar e aprender não apenas "acontecem" em uma sala de aula; mas num ambiente no qual professores e aprendizes saibam ser alfabetizados em mídia (GAPSKI, 2003, p. 74).

Embora as paredes da sala de aula estejam desmoronando, a alfabetização midiática, em perspectiva futura, deve abordar o desenvolvimento profissional e outros recursos necessários para o sucesso em ambientes de educação formal 
(VOLLBRECHT, 2001, p. 47). E como a educação formal considera o fato de que o conteúdo é infinitamente disponível, mais esforços devem ser concentrados no ensino de habilidades de processo de alfabetização midiática, havendo uma necessidade de construir a infraestrutura pedagógica que está faltando em grande escala (BURN, 2007, p. 64).

A alfabetização midiática, portanto, é um movimento. Todos, na sociedade, têm uma participação na alfabetização midiática, pois é fundamental para ter cidadãos capazes em uma democracia que depende do pensamento crítico e da análise de informações (HÜBNER, 2015, p. 57). Apesar da grande interação dos indivíduos com as tecnologias, a compreensão do novo papel da informação e da educação em sociedade ainda é deveras limitada, de modo a tornar premente que a alfabetização midiática seja um movimento de milhões de pessoas desejosas de se habilitarem como hábeis gerentes de informação, consumidores sábios, produtores responsáveis e ativos participantes em suas comunidades.

\subsection{Perspectiva comparada}

A educação para a alfabetização midiática está ativamente focada nos métodos instrucionais e na pedagogia da alfabetização midiática, integrando quadros filosóficos e críticos que surgem da teoria da aprendizagem construtivista, dos estudos da mídia e da pesquisa em estudos culturais (HÜBNER, 2015, p. 64).O uso das mídias e das tecnologias na educação, ao longo do século XX, resultaram no surgimento de interdisciplinaridade nas interseções do trabalho acadêmico em estudos de mídia e educação (HABERMAS, 1987, p. 48).

O mapeamento em perspectiva internacional comparada sobre a alfabetização midiática pode ser observado pelos resultados apresentados no projeto The Voices of Media Literacy, desenvolvido pelo Center for Media Literacy e patrocinado por Tessa Jolls, que contempla entrevistas em primeira pessoa com 20 pioneiros da alfabetização midiática ativos antes dos anos de 1990 em países de língua inglesa (CML, 2018).

O contexto histórico da caminhada da disciplina de alfabetização midiática de indivíduos, segundo a publicação de 2017 do projeto, traz informações sobre GrãBretanha, Austrália, África do Sul, Canadá, Estados Unidos, com um interesse crescente 
na Holanda, Itália, Grécia, Áustria, Suíça, Índia, Rússia e entre outras nações. Todavia, a educação midiática tem sido bastante ampliada em muitos países, tendo na Dinamarca, Noruega e no Canadá grandes expoentes nessa dimensão de ensino.

A alfabetização midiática vem se desenvolvendo no Reino Unido desde a década de 1930. Na década de 1960, houve uma mudança de paradigma no campo da alfabetização midiática para enfatizar a educação dentro da cultura popular, ao invés de atacá-la como um fenômeno social destrutivo, bem como buscando construir valores acerca das artes e expressões culturais populares. Em seguida, na década de 1970, houve a compreensão de que o poder ideológico da mídia estava ligado à naturalização da imagem (WALLIS; BUCKINGHAM, 2013, p. 528).

O foco da alfabetização midiática, por conseguinte, migrou seu foco para o consumo de imagens e representações, quando os primeiros cursos formais de estudos cinematográficos foram criados e, mais tarde, os Estudos de Mídia foram estabelecidos como opções para os jovens na faixa etária de 14 a 19 anos, com adesão de mais de 100.000 estudantes (cerca de 5\% dessa faixa etária) cursando tais disciplinas anualmente (CML, 2018).

A Escócia sempre teve um sistema educacional separado do resto do Reino Unido e começou a desenvolver políticas de educação para a mídia nos anos 80 . Na Inglaterra, a criação do Currículo Nacional em 1990 incluía alguns requisitos limitados para ensinar sobre a mídia como parte da língua inglesa. Na Escócia, os professores podem ser representados pela associação profissional Association of Media Educators, Scotland (AMES); enquanto, na Inglaterra, a Media Education Association (MEA) cumpre esse propósito (WALLIS; BUCKINGHAM, 2013, p. 534).

O Reino Unido é amplamente considerado como um líder no desenvolvimento da educação para a alfabetização midiática. Depois de uma explosão inicial de atividade, entretanto, o trabalho da Ofcom foi mitigado progressivamente e a promoção da alfabetização midiática foi reduzida a uma questão de pesquisa de mercado - o que Wallis e Buckingham (2013, p. 539) descreveram como política de mortos-vivos.

Nos vários países da Europa, a educação para a mídia tem sido abordada de muitas formas diferentes. A educação para a mídia foi introduzida no currículo elementar finlandês em 1970 e nas escolas secundárias em 1977. Mas a educação para a mídia, em sua configuração mais recente, não evoluiu na Finlândia até os anos 90 
(EAO, 2016, p. 32). A educação para a mídia tem sido compulsória na Suécia desde 1980 e, na Dinamarca, desde 1970 (Ibidem, 2016, p. 46 -59). Em ambos os países, a educação para a mídia evoluiu nas décadas de 1980 e 1990, à medida em que a educação midiática se afastou gradualmente de atitudes moralizantes em direção a uma abordagem mais voltada para o aluno, mas tem a Dinamarca maior interesse na educação para a tecnologia da informação (UNESCO, 2013, p. 84). Todavia, desponta a Dinamarca e a Finlândia como as nações líderes na inserção da aprendizagem midiática nas bases curriculares nacionais

A França tem o ensino do cinema instituído desde a década de 1950, mas foi apenas recentemente que conferências e cursos de mídia para professores foram organizados com a inclusão da aprendizagem midiática (CML, 2018). A Alemanha viu publicações teóricas sobre alfabetização midiática nas décadas de 1970 e 1980, com um crescente interesse pela educação midiática dentro e fora do sistema educacional nas décadas de 80 e 90 (GAPSKI, 2001, p. 27 -41). Na Holanda, a alfabetização midiática foi introduzida nos currículos nacionais em abril de 2008, quando um centro oficial foi criado (mediawijsheid expertisecentrum) pelo governo holandês, atuando como organização de rede existente de diferentes parceiros que têm sua própria experiência com o tema da educação para a mídia.

Entre os anos de 1970 a 1990, a Rússia implementou os primeiros programas oficiais de educação em cinema e mídia, publicados pelo Ministério da Educação, expandindo para cursos de mestrado e doutorado, mediante inserção da educação midiática na teórica experimental e no trabalho prático sobre educação para a mídia ${ }^{2}$ Desde 2002, a Rússia adotou o modelo de especialização para as universidades pedagógicas em Media Education em parceria com o ICOS-UNESCO Informação para Todos. Além disso, foram criados os sites da Internet da Associação Russa de Cinema e Educação para Mídia (versões em inglês e russo). Levando em conta o fato de que a UNESCO define a educação midiática como o campo prioritário do desenvolvimento educacional no século XXI, a alfabetização midiática tem boas perspectivas na Rússia (UNESCO, 2018, p. 130). O gráfico abaixo complementa as informações, conforme os seguintes dados:

\footnotetext{
${ }^{2}$ Alguns dos expoentes russos na educação e na aprendizagem midiática são O.Baranov (Tver), S.Penzin (Voronezh), G. Polichko, U.Rabinovich (Kurgan), Y.Usov (Moscou), Alexander Fedorov (Taganrog) A. Sharikov (Moscou) e outros.
} 
Figura 1: Ranking dos países europeus em maior aplicação e desenvolvimento da Aprendizagem Midiática

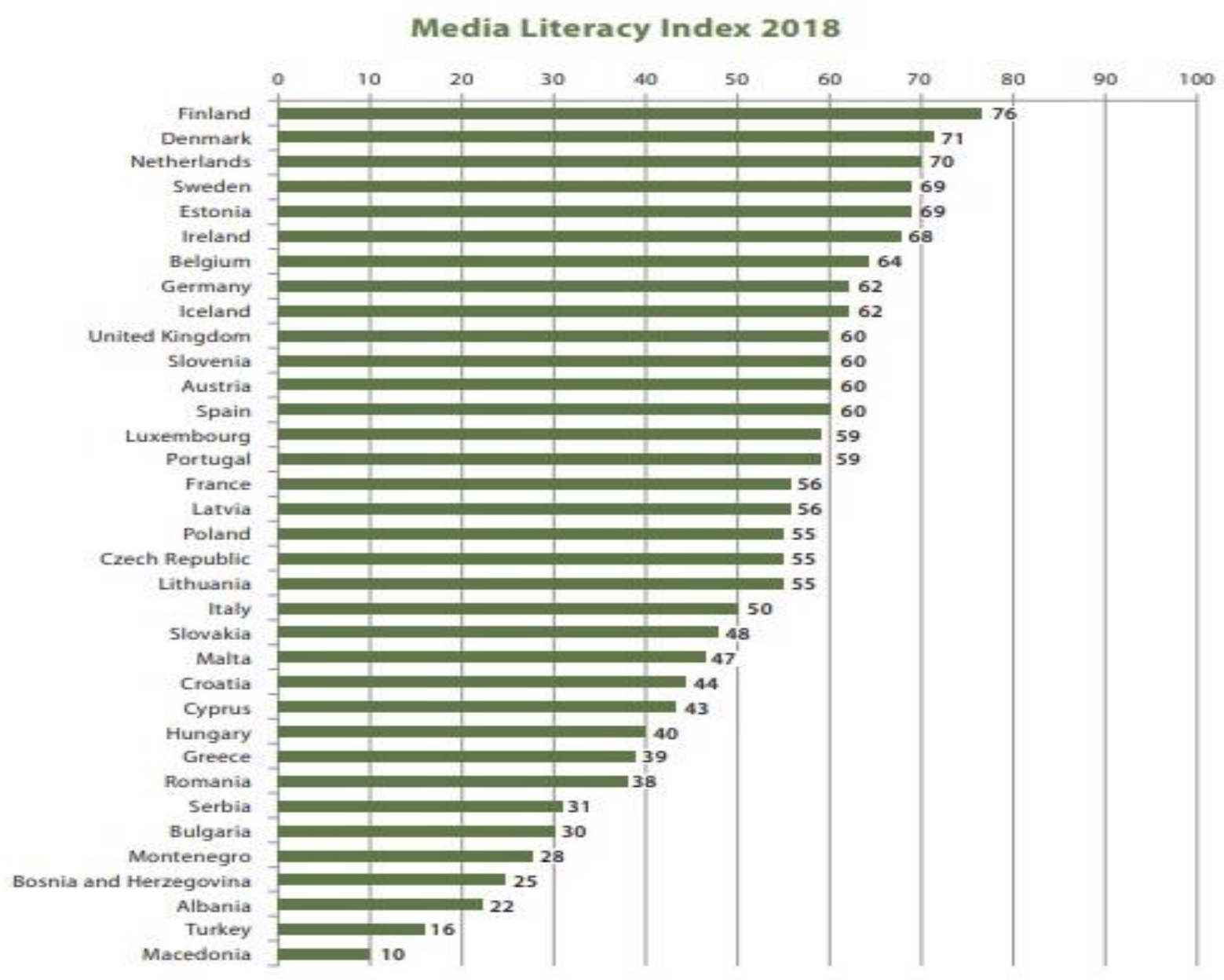

Fonte: Open Society Institute - SOFIA, 2018.

No Canadá, o início de uma abordagem formalizada sobre a alfabetização midiática como um tópico da educação é frequentemente atribuído à formação da Associação de Alfabetização de Mídia (AML), em 1978, com sede em Ontário. O lançamento da educação para a mídia no Canadá surgiu por dois motivos. Um deles derivado da preocupação com a difusão da cultura popular americana e a outro advindo da necessidade de contextos para novos paradigmas educacionais, orientados pelo sistema educacional (UNESCO, 2018, p. 84). 
Desde o início do século XX, a alfabetização midiática tem espaço no pensamento educacional nos Estados Unidos, quando teve início a utilização em sala de aula de filmes, comerciais e animações, para desenvolver o pensamento crítico e as habilidades de comunicação dos alunos, momento em que os educadores aprenderam uma nova terminologia ligada à literatura, à propaganda de mercado e à história (POTTER, 2016, p. 112). Tipicamente, a educação em mídia dos EUA inclui foco em notícias, publicidade, questões de representação e propriedade de mídia. A educação para a alfabetização midiática começou a aparecer nas estruturas curriculares estaduais de educação em inglês no início dos anos 90, como resultado do aumento da conscientização sobre o papel central da mídia visual, eletrônica e digital no contexto da cultura contemporânea (POTTER, 2016, p. 136).

Não há dados nacionais sobre o alcance dos programas de alfabetização midiática nos Estados Unidos. A evolução das tecnologias de informação e comunicação expandiu o tema da alfabetização midiática para incorporar a competência em informática, a colaboração e a resolução de problemas, e a ênfase nas responsabilidades sociais da comunicação (UNESCO, 2018, p. 26).

\section{UM DESAFIO À APRENDIZAGEM MIDIÁTICA: PUBLICIDADE ESTRUTURADA PARA CRIANÇAS E ADOLESCENTES}

Uma das grandes funções da educação midiática é desenvolver a consciência crítica e cidadã, desde as fases mais precoces da formação do indivíduo e do fomento de sua participação na sociedade como um agente responsável, participativo e com capacidade de discernir de maneira embasada, acerca do estado de coisas que compõe o seu ecossistema individual, familiar e coletivo.

Nessa perspectiva, a Organização das Nações Unidas para a Educação, a Ciência e a Cultura (UNESCO) define a primeira infância de 0 a 8 anos de idade, para efeitos do direito da publicidade, enquanto a definição de criança varia de uma jurisdição para outra. No entanto, a idade de 12 anos é comumente usada como um ponto de corte. Esse ponto de corte funciona como base suficientemente próxima da visão acadêmica generalizada de que, até 12 anos, as crianças, ao desenvolverem seu comportamento 
como consumidores, podem efetivamente reconhecer a publicidade e são capazes de adotar atitudes críticas em relação a ela (VALKENBURG, CANTOR, 2001, p. 22).

A publicidade para crianças é o ato de comercializar ou anunciar produtos ou serviços para o público infantil, conforme definido pela legislação nacional e pelos padrões de publicidade. Muitas vezes, é objeto de debate, relacionado à suposta influência sobre o consumo de crianças pequenas (MCNEAL, 1999, p. 29). Na maioria dos países, a propaganda para crianças pequenas é enquadrada por uma mistura de legislação e autorregulamentação publicitária (GUNTER et al, 2004, p. 15), mas fica distante da alfabetização midiática.

Nos séculos XIX e XX, a educação compulsória de crianças foi estabelecida em muitos países, o que, consequentemente, tornou as crianças um público alvo para muitas publicações, além dos já comercializados produtos infantis, como brinquedos e cosméticos. Os comerciais também apelavam para as crianças; no entanto, estes não se tornaram comuns até o advento e adoção generalizada do rádio e da televisão. Com popularização da televisão a cabo, na década de 1990, o apelo dos comerciais para as crianças cresceu exponencialmente (MCNEAL, 1992, p. 23 - 34), contando com canais de conteúdo exclusivo para o público infantil ou adolescente (teen).

Nesse período, revistas em quadrinhos também começaram a vender objetos com logos e personagens, mas não foram inicialmente direcionados para as crianças, porque essas eram enxergadas como não possuidoras de poderes aquisitivos e decisórios. Tal fato se provou equivocado, quando as pesquisas indicaram as crianças como sendo o grupo majoritário entre os "consumidores" (OLSON, THJOMOE, 2012, p. 1727) desses produtos.

Para os anunciantes, a radiodifusão expandiu a capacidade de se comunicarem com os consumidores de maneira eficaz e plurifacetada (HOLZ, 2017, p. 50 - 52). A propaganda pontual, uma nova forma de promoção nessa época, passou a ser conhecida como uma forma prodigiosa de publicidade, marcadamente retratada em publicidades televisivas cujos anúncios aparecem entre os programas (GUNTERS et al, 2004, p. 39). No entanto, a publicidade pontual não foi a única promoção comercial a se tornar popular. Arranjos de patrocínio também começaram a aparecer. Os anunciantes vinculavam seu nome a determinados programas de TV ou filmes, e suportavam parte 
do custo de produção, para promoverem os seus produtos por meio de mídia de transmissão (HOLZ, 2017, p. 69 - 71).

A partir dos anos 2000, uma oportunidade significativa surgiu para anunciantes e profissionais de marketing com um número maior de usuários da Internet devido à popularização do computador doméstico, desde os últimos anos da década de 1990. Esse movimento expandiu mais formas de publicidade e intensificou a relação entre profissionais de marketing e consumidores (MCNEAL, 1999, p. 26).

Segundo Seiter (1993, p. 22), as tensões entre pais e filhos sofreram uma transformação histórica, lastreadas principalmente na cultura midiática contemporânea, enquanto os desejos das crianças estavam no processo de ganhar legitimidade tanto pública quanto doméstica, pois surgiu uma preocupação de que as crianças pequenas tinham uma desvantagem significativa nessa forma secreta de marketing, pois a publicidade poderia ser capaz de induzi-las, devido à pouca maturidade em compreender o objetivo implícito dos anunciantes (REIHER, ACUFF, 2008, p. 65).

Sob tal prisma, Schor (2004, p. 65) investigou as práticas e motivações das indústrias de pesquisa e publicidade de mercado das crianças contemporâneas, expondo algumas das profundas patologias da cultura de mercado, de modo que a transformação da criança "fofa", maravilhosa, foi transmutada materialmente numa figura desafiadora e recalcitrante a ordens não fundamentadas e discursos de autoridade, muitas vezes ameaçando e agindo por conta própria, sem o terror referencial à figura dos pais.

Sammond (2005, p 25 -107), através do estudo de obras da Disney, fornece um modelo para investigar como os esforços de vários atores - comerciais, acadêmicos e governamentais - combinaram involuntariamente para construir um modelo de uma criança "genérica", que, por sua vez, assumiu o caráter de um sujeito natural que informa a ação subsequente para atores do mercado, educadores, pedagogos, psicólogos e outros, conforme produtos audiovisuais e jogos virtuais de maior sucesso sazonal.

Tais fenômenos podem ser compreendidos também na obra de Pugh (2009, p. 98) quando sugere que as crianças se preocupam menos com os bens em si do que com a "dignidade social" que os bens proporcionam, permitindo que elas pertençam a um mundo social, descobrindo que grande parte dos esforços dos pais é direcionada a administrar a capacidade de pertencer a seus filhos, retratando a interferência direta da 
publicidade na forma como as crianças compreendem a si mesmas e o universo no qual estão inseridas.

Para este autor, as liberdades de propaganda e em marketing digital, na rede mundial de computadores têm variados motivos, dentre eles: (I) a falta de regulamentação e normatização nacionais e internacionais; (II) a dificuldade de um sistema de tributação eletrônica efetiva; (III) a sonegação comissiva por parte de contratantes, anunciantes e cedentes no espaço virtual; (IV) a facilidade de exclusão ou modificação de anúncios; (V) a efemeridade de duração dos anúncios; (VI) as atualizações publicitárias realizadas continuamente por inteligências artificiais (VII) o uso de publicidade direcionada; e (VIII) o desinteresse da população e de agentes públicos.

Com a ampliada acessibilidade a dispositivos eletrônicos como smartphones, tablets, computadores, notebooks, videogames, smart TVs e serviços de streaming, todos com conexão em linha, as formas de entretenimento também foram diversificadas e entregues mediante variadas plataformas e aparelhos (BOSTROM, 2014, 51). Nesse contexto, o marketing também se adaptou e, visando o público infantil, pode ser ofertado com maior liberalidade e em maior quantidade do que nos veículos tradicionais de comunicação (KOTLER, KARTAJAYA, 2017, p. 105).

A compreensão de anúncios pelas crianças mais novas pode diferir das mais velhas, tendo em vista os interesses de cada faixa etária e as mudanças decorrentes de uma fase de absorção de ensinamentos de maneira acrítica (SCHOR, 2004, p. 74). Segundo o estudo da APA (KUNKEL et al, 2004, p. 28), crianças mais novas são mais confiantes e acreditam que o produto mostrado no anúncio será exatamente como aparece na TV se eles o comprarem. Os arredores do produto mostrado no anúncio também influenciam o modo de percepção infantil do anúncio. Um ambiente colorido e divertido irá capturar a atenção e tornar o anúncio mais memorável, pois visto como uma forma de entretenimento, crianças costumam desfrutar de anúncios de forma semelhante ao modo como aproveitariam de um programa de TV.

O mesmo estudo da APA (KUNKEL et al, 2004, p. 32) mostra que crianças mais velhas são mais capazes de entender o significado por trás dos anúncios e podem reconhecer certos aspectos capazes de influenciar suas decisões de compras, também criticando produtos previamente conhecidos e tidos como não são exatamente iguais aos 
retratadas no anúncio, de modo a paulatinamente formarem concepções mais realistas. As crianças mais velhas reconhecem que o humor, a música e a ação são usados para captar sua atenção, além de ajudá-las a lembrarem-se do anúncio, podendo apenas se divertirem com a propaganda, independentemente de estarem interessadas no que está sendo anunciado, ao contrário das crianças pequenas, cujo interesse é voltado para produtos que elas próprias querem ou já possuem.

Tais dados podem ser estendidos para a realidade das plataformas virtuais acessadas através de dispositivos eletrônicos (KOTLER, KARTAJAYA, 2017, p. 159). Conforme já comentado, os profissionais de marketing são afetados pelas leis de transmissão de publicidade na TV para crianças pequenas. Há muitos papéis estereotipados apresentados a meninos e meninas na publicidade e tais anúncios mostram às crianças como a sociedade vê seus estereótipos de gênero em diferentes categorias.

Entretanto, a falta de maturidade para distinguir os excessos da publicidade nas plataformas digitais, associadas com a impossibilidade de controle por parte dos pais quanto aos conteúdos acessados, fazem com que crianças sejam bombardeadas com anúncios e marketing de todos os tipos e intensidades (PUGH, 2009, 247), enquanto desfrutam de acesso a muitos sítios eletrônicos suspeitos ou manuseiam equipamentos os quais, muitas vezes, possuem dispositivos de áudio, câmera e microfone.

Dessa forma, é imprescindível que pais sejam conscientes da liberdade da internet e participem mais ativamente dos acessos de seus filhos, monitorando tanto o conteúdo acessado (HOLZ, 2017, p. 79), quanto a espécie de publicidade vinculada a este e que, estando conscientes da liberalidade e do "lassez-faire" avalizado pela Administração face à publicidade virtual, compreendam como as garantias do Estado de Direito acabam ficando mitigadas no campo da tecnologia e no ambiente digital.

\subsection{O consumo infanto-juventil no Brasil}

Como fruto desses fenômenos, o consumo no Brasil fomentado por crianças apresenta curiosos dados quantificados. A influência das crianças sobre compras pode ser melhor compreendida pelo gráfico a seguir, o qual demonstra os setores de maior interesse infantil, quando da escolha por bens a serem adquiridos. O gráfico é fruto de 
uma pesquisa realizada pelo Serviço de Proteção ao Crédito (SPC Brasil), em 2015, e traz as seguintes informações:

Figura 2: Poder de escolha das crianças sobre espécies de produtos.

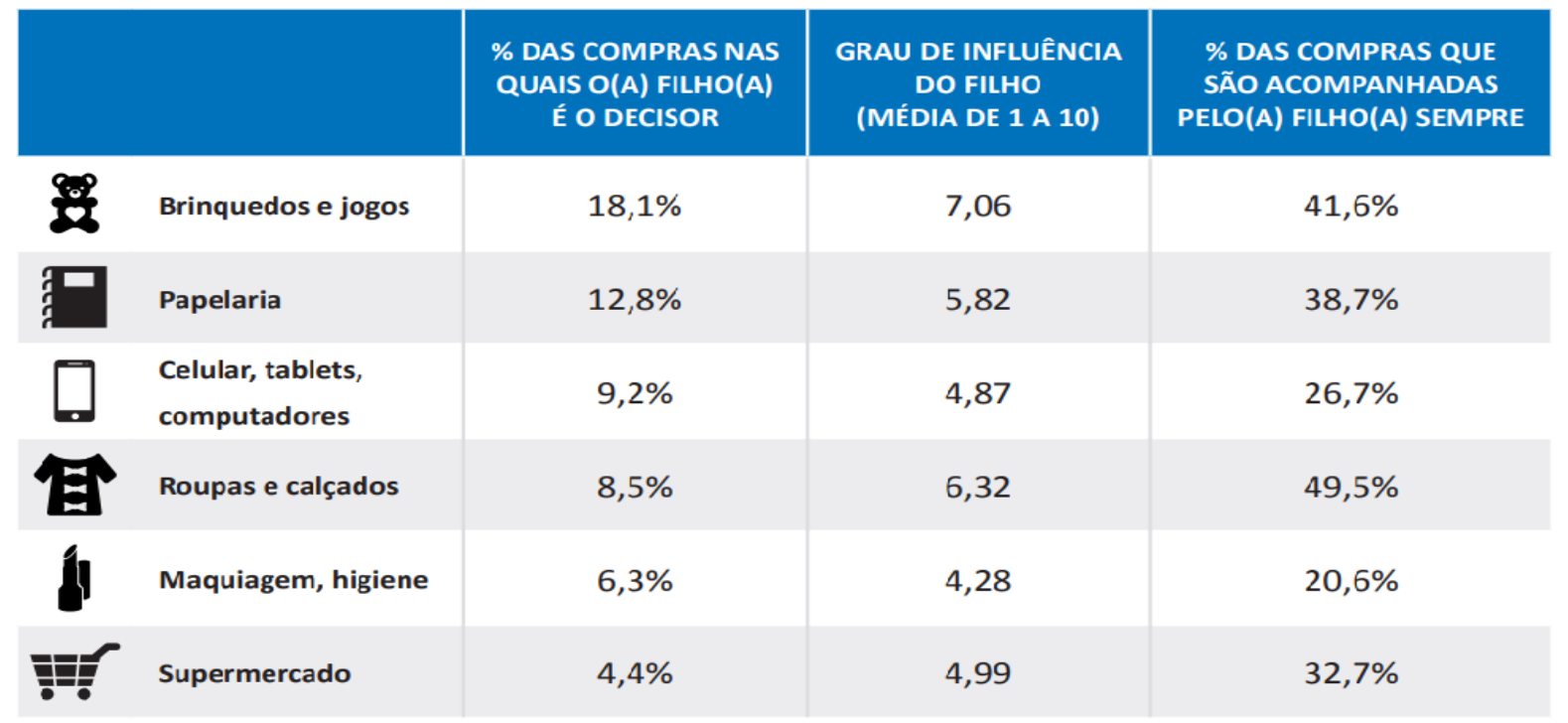

Fonte: Serviço de Proteção ao Crédito - SPC Brasil, 2015, p. 11.

Assim, é possível notar que brinquedos, artigos de papelaria e a compra de eletrônicos estão entre os itens mais requisitados pelas crianças, com a participação direta na sua compra, bem como existe forte influência infantil na escolha sobre compras das famílias também.

Uma pesquisa realizada pela Associação Americana de Psicologia (APA), apontou que crianças menores de oito anos são mentalmente incapazes de ver e interpretar anúncios de televisão com um olhar crítico. De acordo com a APA, as crianças pequenas são mais propensas a aceitar propagandas como verdadeiras, precisas e imparciais do que as crianças mais velhas, ainda que os adultos sejam capazes de reconhecer o objetivo persuasivo e, por vezes, mentiroso, da publicidade. Crianças com menos de seis anos têm dificuldades em separar os comerciais da programação normal da televisão (APA, 2004, p. 12 - 16).

De acordo com a pesquisa da APA (KUNKEL et al, 2004, p. 34), existem impactos negativos sobre as saúdes física e mental das crianças. A publicidade cria uma lógica de moral relativizada pelo poder de consumo e pode ser prejudicial para um desenvolvimento psicossocial adequado. Com o início da "era da informação", parte 
considerável das vidas das crianças reflete-se em tempo gasto assistindo televisão, filmes, ou utilizando aparelhos eletroeletrônicos, com softwares embarcados e conectados à Internet e, por sua vez, recebendo diariamente exposição a um contingente de anúncios, capazes de estimular formas de modo de vida, comportamento, valores, visão de consumo e metas (OLSON, THJOMOE, 2012, p. 1739).

Os efeitos mais nefastos da manipulação pelo marketing para crianças pequenas e suas famílias são o mal-estar interpessoal, o constrangimento, as discussões e até comportamentos agressivos (REIHER, ACUFF, 2008, p. 115), tendo em vista os desejos das crianças em consumirem os produtos anunciados e a decisão dos pais de não fornecê-los no momento requisitado (SCHOR, 2004, 234).

Um exemplo é o Fator de Incômodo ou "Nag Factor", como o fenômeno é conhecido na literatura dos Estados Unidos; trata de uma tendência das crianças, de dizerem aos pais o que querem e, com a repetição da visualização, continuam a lembrar aos pais, incomodando-os e importunando-os, para comprarem coisas as quais desejam (MCNEAL, 1999, p. $75-86$ ).

Tanto nas épocas festivas, como aniversário ou Natal, quanto durante compras em lojas e supermercados, as crianças podem incomodar os pais ao reconhecerem marcas às quais já estão habituadas com a respectiva propaganda do "dever-ter", à medida em que o desejo cresce sempre quando visualiza o determinado produto almejado (NICHOLS, CULLEN, 2004, p. 79). Embora as propagandas nem sempre sejam o motivo de as crianças pequenas importunarem seus pais nas lojas, elas naturalmente são atraídas por itens específicos e decidem rapidamente o que gostam e o que não gostam, pois querem possuir tal como os demais (amigos, colegas, parentes) possuem também (VALKENBURG, CANTOR, 2001, p. 135)

No Brasil, a pesquisa feita pelo SPC (2015, p. 22) revela quais os graus de influência e interesse de crianças, na hora das compras, e quais são as principais escolhas consideradas pelo público infantil, conforme o gênero, faixa etária e classe social, conforme o gráfico ilustra a seguir:

Figura 3: Influência de crianças na hora das compras 


\begin{tabular}{|c|c|c|c|c|c|c|c|c|}
\hline \multirow{2}{*}{ RU } & \multirow{2}{*}{ GERAL } & \multicolumn{2}{|c|}{$\begin{array}{l}\text { SEXO DO(A) } \\
\text { FILHO(A) }\end{array}$} & \multicolumn{3}{|c|}{ IDADE DO(A) FILHO(A) } & \multicolumn{2}{|c|}{ CLASSE } \\
\hline & & MASC. & FEM. & $\begin{array}{l}2 \text { A } 5 \\
\text { ANOS }\end{array}$ & $\begin{array}{l}\text { 6A } 11 \\
\text { ANOS }\end{array}$ & $\begin{array}{l}12 \text { A } 18 \\
\text { ANOS }\end{array}$ & $\mathrm{A} / \mathrm{B}$ & $C / D / E$ \\
\hline $\begin{array}{l}\text { Personagens licenciados } \\
\text { - brinquedos }\end{array}$ & 5,79 & 5,81 & 5,78 & 7,19 & 6,15 & 4,76 & 5,87 & 5,68 \\
\hline $\begin{array}{l}\text { Personagens licenciados } \\
\text { - material escolar }\end{array}$ & 5,71 & 5,55 & 5,88 & 6,71 & 5,78 & 5,14 & 5,75 & 5,66 \\
\hline $\begin{array}{l}\text { Produtos Ilicenciados - } \\
\text { roupas e calçados }\end{array}$ & 5,70 & 5,62 & 5,78 & 6,86 & 5,64 & 5,14 & 5,68 & 5,72 \\
\hline Propagandas na TV & 5,58 & 5,75 & 5,4 & 5,36 & 5,88 & 5,44 & 5,7 & 5,41 \\
\hline Amigos e Famfila & 5,27 & 5,2 & 5,35 & 4,45 & 5,37 & 5,62 & 5,37 & 5,14 \\
\hline Brindes Colecionsveis & 4,86 & 5,27 & 4,45 & 4,61 & 5,26 & 4,65 & 5,05 & 4,61 \\
\hline Marcas Famosas & 4,58 & 4,89 & 4,26 & 3,59 & 4,43 & 5,22 & 4,65 & 4,49 \\
\hline Embalagens atrativas & 4,56 & 4,63 & 4,49 & 4,70 & 5,04 & 4,07 & 4,81 & 4,21 \\
\hline
\end{tabular}

Fonte: Serviço de Proteção ao Crédito - SPC Brasil, 2015, p. 22.

A moralidade das crianças (SAMMOND, 2005, p. 159) pode ser distorcida, por exemplo, quando anunciada a compra de um presente para um colega, com o intuito de definir como um relacionamento é valorado, levando as crianças a pensarem que a natureza dos relacionamentos é baseada unicamente em presentes ou itens tangíveis. Muitas crianças podem pensar que "compras = identidade". Tal conceito pode fazer com que a criança julgue uma pessoa pelo seu nível de status e pelas coisas que a pessoa possui. Além disso, como a ideia de julgamento e o valor que ela detém ainda não foram desenvolvidos completamente, a mentalidade das crianças pode se basear em parâmetros que relacionem o "mais caro é melhor" (PUGH, 2009, 48).

Esse tipo de propaganda pode ser argumentado como antiético, pois sugere um modo de vida, que coloca os valores materialistas à frente dos relacionamentos e molda o modo pelo qual as crianças acreditam que o mundo pode estar quando estiverem mais velhas; enganando-os.

3.2 Relações econômicas, privacidade de dados pessoais e a validade de atos jurídicos de crianças e adolescentes 
A presença massificada de crianças e adolescentes em ambiente virtual também aduz desdobramentos no campo econômico, sobre a privacidade de seus dados pessoais e quanto à validade de atos jurídicos praticados on-line. Nesses aspectos, a educação midiática também desponta como uma disciplina capaz de colaborar com a formação cidadã de indivíduos em fase de desenvolvimento psicossocial, ao passo que complementa uma conscientização sobre boas práticas que deve ser iniciada no ambiente familiar.

O relatório produzido pelo Tic Kids On-line Brasil (2017), sob o enfoque da conectividade e dinâmicas de uso das plataformas eletrônicas, ao avaliar o acesso das crianças e adolescentes nos últimos três meses em sua periodicidade; faixa etária; sexo; área de acesso; classe social e escolaridade dos pais ou responsáveis, possibilitou a colheita das seguintes informações: (I) as crianças e os adolescentes, em sua maioria, acessaram a internet diariamente (85\%) ou em intervalo não superior a 03 (três) meses; (II) há predomínio de acesso na área urbana sobre a rural; (III) existe equilíbrio em relação ao sexo (com o feminino na margem de $86 \%$ e o masculino com $85 \%$ ) e com relação à faixa etária (com a seguinte distribuição; (a) de 5 a 10 anos $=74 \%$; (b) de 11 a 12 anos $=82 \%$; (c) de 13 a 14 anos $=87 \%$ e (d) de 15 a 17 anos =93\%); (IV) ao se levar em consideração a escolaridade dos pais ou responsáveis, a categoria de destaque é do "ensino médio ou mais" com 93\% e (V) sobre a classe social o destaque fica por conta da $\mathrm{AB}$ com $98 \%$.

Além disso, no mesmo relatório, é possível constatar que, diante de apenas uma opção de acesso à Internet, há predominância do telefone celular, enquanto diante do uso simultâneo de telefone celular e computador, a vantagem daquele sobre este fica bastante reduzida. Com o foco voltado para a Mediação e uso seguro da internet, o relatório em análise aponta que as crianças e adolescentes que usam a internet com segurança, segundo declaração dos seus pais ou responsáveis alcançou a margem de $70 \%$, enquanto a margem sobre o tipo de orientação recebida dos seus pais ou responsáveis para o uso da internet registrou $84 \%$.

A significativa presença de crianças brasileiras nas redes sociais fazem do Brasil o segundo maior consumidor de vídeos do YouTube no mundo, segundo a instituição EU Kids On-line ${ }^{3}$, cuja pesquisa aponta, em seus resultados, ser "possível identificar

\footnotetext{
3 "Children and Internet use: A comparative analysis of Brazil and seven European countries"
} 
entre os 100 canais de maior audiência no YouTube Brasil 48 canais que abordam conteúdo direcionado ou consumido por crianças de 0 a 12 anos", sendo que, dentre os canais infantis mais acessados, têm-se, em primeiro lugar, 58 canais de Games/Minecraft; 35 de programação não disponível na televisão; 26 propaganda de brinquedos; 61 Youtubers mirins; 14 Youtubers teen e 1 educativo (SOZIO, et al, 2015, p. 03).

Nesse sentido, a atuação de youtubers mirins pode ensejar a "monetização", que é um sistema de pagamento pecuniário ao titular do canal, baseado na permissão de realização de anúncios publicitários (propagandas), de curta ou média duração, antes da exibição de cada vídeo, de modo que o valor repassado ao titular do canal é calculado conforme o respectivo número de visualizações. Portanto, é possível observar que existe uma subespécie de trabalho infantil, autônoma ou semiautônoma, mas exercida sem fiscalização estatal ou regulamentação tributária individualizada, caracterizada pela relação econômica.

De forma mais específica, diante do mapeamento sobre o consumo e a produção infantil de vídeos para crianças de zero a 12 anos no Brasil, realizado entre 2015 e $2016^{4}$, ao analisar a audiência e a popularidade dos Youtubers minis, constatou-se que dos 100 canais de maior audiência no Brasil, 36 abordam conteúdo direcionado ou consumido por crianças, em 2015, enquanto 48 abordam conteúdo direcionado ou consumido por crianças, em 2016. Além disso, de 2015 para 2016, houve aumento de $564 \%$ no número de visualizações dos canais e youtubers mirins e de $550 \%$ no número de inscritos em canais de youtubers mirins (CORREA, 2016, p. 06). Importante destacar que, diante das definições da plataforma acerca do equipamento utilizado para acessar o Youtube, os tablets e celulares são os preferidos, independentemente, de serem próprios ou da família (SOZIO, et al, 2015, p. 03).

Esse acesso marcante das crianças e adolescentes brasileiros na internet ao ser comparado com sete países europeus, apontou "uma significativa presença de crianças e jovens brasileiros nas redes sociais comparada aos demais países", segundo a pesquisa da instituição Media LAB, $78 \%$ das crianças e adolescentes brasileiros usuários de

\footnotetext{
${ }^{4}$ Geração Youtube: um mapeamento sobre o consumo e a produção infantil de vídeos para crianças de zero a 12 anos no Brasil, de 2015 a 2016, por Luciana Corrêa
} 
internet possuem perfil próprio em redes sociais, enquanto na Dinamarca, eles representam $81 \%$ e, na Romênia, 78\%. O dado que colocou o Brasil em destaque cuida do acesso de crianças de 9 e 10 anos serem as mais presentes com 52\%, seguido da Romênia (50\%), Dinamarca (41\%), Portugal (26\%), Bélgica (22\%), Reino Unido (19\%), Itália (15\%) e Irlanda (14\%). Dentre as atividades de acesso à internet, a mais citadas por crianças e adolescentes entre 11 e 16 anos em todos os países do mundo estão relacionadas a assistir aos vídeos ou clipes (CORREA, 2016, p. 12).

A exposição de crianças e adolescentes também ocorre sob o aspecto da proteção de dados pessoais, que, segundo definição legal, são caracterizados como "sensíveis", por se tratarem seus titulares de indivíduos menores de idade. Para participação em muitos sítios eletrônicos e utilização de aplicativos, jogos e serviços de streaming, é necessário possuir pelo menos uma conta de correio eletrônico e, conforme arquitetura de desenvolvimento das plataformas e regras de utilização da empresa, são exigidas informações diversas, desde nome completo, a números de documentos, filiação e endereço residencial - o que agrava a vulnerabilidade relativa à exposição.

Nesse contexto em que as crianças e adolescentes se inserem no mundo digital de forma marcante, os publicitários não tardaram em lançar seus produtos nos principais canais de vídeos e games, com vasta incidência do setor de marketing, principalmente, para produtos licenciados, conhecidos como advergames. Os advergames são considerados uma das formas mais promissoras de alcançar o mercado jovem e tem como objetivo principal distribuir informações das mensagens de marca, produto e marketing para usuários on-line, integrando-as ao processo de jogo (AN, et al., 2014, p. 64)

Algumas das vantagens de usar os advergames estão diretamente relacionadas ao custo, que é relativamente barato e poucas restrições legais os envolvem. Outra vantagem dos advergames é que os anunciantes podem avaliar quanto tempo o usuário está envolvido com seus jogos de marca, o que simplifica o processo de coleta de dados e gera economia nos custos de marketing. Assim, diante dos dados coletados e com a ajuda dos psicólogos que analisam o comportamento, as fantasias e sonhos das crianças, os anunciantes têm uma compreensão profunda das necessidades emocionais e de desenvolvimento (AN, et al, 2014, p.67). Do contraste entre a proteção integral da criança e do adolescente com as estratégias da análise dos advergames alinhada aos 
conhecimentos psicólogos é que o uso das informações que tratam do funcionamento da mente da criança voltadas para a exploração comercial tem sido vista como antiéticas e conduzido vários países ao endurecimento das restrições legais impostas à publicidade para crianças (HOLZ, 2017, p. 157). Assim:

\begin{abstract}
A criança aqui não é vista primariamente em termos desenvolvimentistas, como uma categoria definida apenas pela idade. Ao contrário disso, há uma ênfase na diversidade das infâncias (no plural), especialmente em termos de classe social, gênero e etnia. Sob esta perspectiva, o significado de ser criança não é algo fixo ou dado, mas algo que é socialmente construído e negociado (BUCKINGHAM, 2008, p. 99).
\end{abstract}

A diversidade de comportamento, exposição, incentivo, além da influência sofrida por crianças e adolescentes em decorrência da relação por elas estabelecidas com a mídia e as tecnologias têm gerado um sem par de possibilidade de perfis afetados ou vitimizados, o que tem afastado os parâmetros nos quais as crianças eram entendidas e enquadradas.

A autonomia da vontade é questão que, inserida no contexto virtual,1 ganha contornos complexos em decorrência dos envolvidos na cadeia de fornecimento, que pode ser composta por vários participantes, principalmente, quando inserida no campo dos contratos, o que nos dizeres de Marques vem ilustrado na seguinte hipótese:

[...] o cocontratante (por exemplo, uma livraria eletrônica), o organizador da cadeia (por exemplo, um portal ou um serviço de busca), o "representante" (por exemplo, aquele que aparece como franqueado, com a marca do franqueador, com o logotipo do representado), o provedor de acesso (por exemplo, quando o provedor participa, por qualquer meio, diretamente das atividades previstas no art. 3 do CDC). Ainda temos o fornecedor direto do serviço ou o produtor ou fabricante do produto e seu representante (art. 34 do CDC) e o garantidor, tema importante do papel dos cartões de crédito no comércio com consumidores, excluída apenas a responsabilidade contratual eventual do provedor e do mantenedor do site, que só intermedia a contratação. (MARQUES, 2005, p. 742)

Nesse sentido, a responsabilidade pelos danos causados na Internet envolve fornecedores diretos (pessoas físicas ou jurídicas), intermediários, provedores, certificadores ou quaisquer outros envolvidos na relação. Cabe destacar que, aos provedores, diante de seus próprios atos, a responsabilidade civil deve ser interpretada à luz Código Consumerista ou do Código Civil, enquanto por atos de terceiros ou usuários, deve-se lançar mão de previsões que acolham a responsabilidade solidária diante da análise do dolo ou da negligência, como prevê a Lei nº 12.965/2014 (Marco 
Civil da Internet). Lado outro, diante dos certificadores, a responsabilidade deve se voltar para os defeitos advindos da atividade específica acerca da autenticidade ou segurança por eles atestadas.

A responsabilidade dos envolvidos na cadeia produtiva não se limita aos vieses decorrentes da sua atuação, uma vez que precisa ser analisada a responsabilidade dos pais pelos atos praticados por seus filhos e da declaração da vontade expressa no meio digital que é por eles emitida. Isso porque, valendo-se de dados pessoais salvos nos aparelhos dos pais e da impessoalidade intrínseca às comunicações virtuais, as crianças podem efetuar contratações que não guardam relação com os interesses próprios de quem é o legítimo possuidor dos dados. Diante da contratação concretizada por uma criança, advém a regra da imputabilidade, todavia, ao se tratar de contratação eletrônica, o nexo causal deve ser objeto de análise para se aferir a imputação da vontade, a quem, inicialmente, não a possui. (LORENZETTI, 2004, p. 291-293). A relativização da responsabilidade voltada para a contratação realizada por incapaz em ambiente virtual pode não se limitar ao campo de atuação do nexo causal, em decorrência do controle parental permitido no artigo 29 da Lei ${ }^{\circ} 12.965 / 2014^{5}$.

\section{ALFABETIZAÇÃO MIDIÁTICA NA INFÂNCIA NA PRÁTICA ESCOLAR}

A alfabetização midiática tem por um de seus fundamentos, estar inclusa no currículo escolar como forma de promover o engajamento cívico, aumentar a conscientização sobre as estruturas de poder inerentes à mídia popular e ajudar os alunos a obterem as habilidades críticas e de pesquisa necessárias na sociedade atual (POTTER, 2016, p. 187). Os educadores argumentam há décadas que o ensino da alfabetização midiática na sala de aula é crucial na formação de pensadores críticos, cidadãos bem informados e consumidores conscientes, a fim de estarem cientes dos riscos presentes no uso constante da mídia, do imperativo consumista e da Internet (HUBNER, 2015, p. 75).

\footnotetext{
${ }^{5}$ Art. 29. O usuário terá a opção de livre escolha na utilização de programa de computador em seu terminal para exercício do controle parental de conteúdo entendido por ele como impróprio a seus filhos menores, desde que respeitados os princípios desta Lei e da Lei no 8.069, de 13 de julho de 1990 Estatuto da Criança e do Adolescente. Parágrafo único. Cabe ao poder público, em conjunto com os provedores de conexão e de aplicações de internet e a sociedade civil, promover a educação e fornecer informações sobre o uso dos programas de computador previstos no caput, bem como para a definição de boas práticas para a inclusão digital de crianças e adolescentes.
} 
Neste sentido, a UNESCO sintetizou no estudo Global media and information literacy assessment framework: country readiness and competencies, um corpo crescente de pesquisas enfocando os impactos da alfabetização midiática nos estudantes, em que se busca quantificar intervenções de alfabetização midiática como tendo efeitos positivos sobre conhecimento, crítica, realismo percebido, influência, crenças comportamentais, atitudes, autoeficácia e comportamento social (UNESCO, 2013, p. $34)$.

A era digital facultou a qualquer indivíduo criar uma mídia, muitas vezes sem o compromisso de prestar informações embasadas e fiáveis. Portanto, a alfabetização midiática tornou-se uma habilidade social de grande importância, mesmo havendo algumas barreiras para aprender e ensinar, tais como o acesso a equipamentos eletrônicos, alfabetização tradicional e a própria curiosidade humana em conhecer e desenvolver novas competências.

A publicidade está constantemente progredindo em lugares que cercam as crianças, como nas escolas, em que as crianças não costumavam ser expostas à publicidade e ao consumismo (PUGH, 2009, p. 132). As escolas agora permitem a promoção de marcas em troca de tecnologia e recursos. Algumas formas comuns de publicidade nas escolas incluem patrocínio de equipes esportivas, sinalização em salas de aula, materiais escolares e didáticos e eventos escolares patrocinados. Ao promover marcas e produtos nas escolas, os anunciantes agora alcançam as crianças pequenas. É uma violação ética anunciar para um grupo tão jovem, quando essas empresas e marcas têm o poder de influenciar as crianças de uma forma muito mais positiva, pois encurraladas dentro das suas condições sociais, a fragilidade torna-se aumentada (NASCIMENTO, 2002, p. 71).

Na perspectiva da pandemia do COVID-19, a necessidade de inserção da alfabetização midiática assumiu um protagonismo majorado. Quando do isolamento social, sobretudo em grandes centros urbanos, em que a distribuição demográfica ocorre de maneira vertical, em prédios ou áreas residenciais com pouco espaço para lazer e a convivência em espaços públicos, como parques e praças, não é recomendável, pelo risco de contaminação, a utilização de aparelhos eletroeletrônicos representa um canal de seguro de comunicação entre familiares, de alunos com a escola e de autoridades públicas com a sociedade. 
Assim, a presença de crianças e adolescentes na internet, quer para a consecução de atividades escolares, quer para diversão e socialização, pode se valer da alfabetização midiática, como uma disciplina capaz de aprimorar práticas, habilidades e competências quanto à usabilidade da Internet e de softwares, visando o desenvolvimento psicopedagógico através das novas tecnologias de mídias eletrônicas e virtuais.

Apesar do contexto pandêmico global, as discussões socias prosseguem e as habilidades de pensamento que formam a base da educação para a alfabetização midiática podem ser utilizadas na educação infantil para minimizar questões ligadas à saúde pública, como diminuir o abuso de substâncias em adolescentes e adultos, a ansiedade, a depressão, o respeito ao gênero e à orientação sexual, escolhas sobre alimentos, reflexões sobre consumo e descarte conscientes, combates às doenças sexualmente transmissíveis, à violência e ao suicídio, além da facilitação do acesso a direitos e a compreensão de deveres, na formação de uma sociedade mais cidadã, menos manipulável e melhor habilitada na capacidade de desconstruir criticamente as mensagens da mídia e as intenções capazes de influenciar escolhas, principalmente entre crianças, indivíduos em idade escolar e ainda em formação (UNESCO, 2013, p. 79).

Quando as famílias não conseguem traçar um diálogo educacional e conscientizador, os jovens, adolescentes e crianças, tendem a se revoltarem (WALLIS; BUCKINGHAM, 2013, p. 87) e compensarem suas frustrações na violência, no álcool, drogas, hábitos de compra e de alimentação, criando problemas cujos impactos podem perdurar a longo prazo. A alfabetização midiática, nesse sentido, pode ser uma ferramenta valiosa para prevenir comportamentos prejudiciais à saúde das crianças. Com o auxílio da escola, as crianças podem se tornar educadores sobre boas práticas de utilização das ferramentas midiáticas e virtuais em suas famílias, sobretudo auxiliando seus parentes que não possuem tantas habilidades com os mais recentes aparelhos eletroeletrônicos, sobretudo os idosos, conforme aponta o estudo Mapping of media literacy practices and actions in EU-28 (2016, p. 46 - 70).

O relatório também traz a comento a relação da educação para a alfabetização midiática como ferramenta para combater a obesidade infantil e promover hábitos de consumo saudáveis (EAO, 2016, p. 106). Nesse sentido, a alfabetização midiática introduz estratégias de marketing sobre propagandas alimentícias, ensinando aos alunos como avaliar o valor nutricional dos alimentos anunciados e a promover gêneros de 
víveres mais saudáveis entre seus pares, empregando as estratégias de marketing aprendidas, viabilizando melhorias significativamente maiores no conhecimento nutricional de alimentos, comportamento de compra de alimentos e alfabetização de publicidade de alimentos.

Os programas de alfabetização midiática também podem ser usados como promoção da saúde em geral, utilizando as mídias e tecnologias como fontes ativas de informação, visando reunir e aprender conteúdos sobre saúde sexual, bem como alfabetização midiática (por exemplo, como tomar decisões sobre sexo seguro e como melhorar as habilidades de mídia). Programas de alfabetização midiática se aplicam à prevenção do HIV e outras doenças sexualmente transmissíveis, formas de contágio e tratamento, métodos contraceptivos e gravidez (EAO, 2016, p. 127). Ademais, doenças endêmicas, epidêmicas ou pandêmicas podem ser evitadas ou minoradas, através da difusão de conhecimentos e informações, atualmente acessíveis pela internet e em aplicativos.

A revisão literária remete a uma grande quantidade de pesquisas sobre a exposição de crianças e adolescentes à mídia em todas as suas formas. Todavia, poucos estudos exploram a eficácia de certas ferramentas que podem ser usadas para combater as consequências prejudiciais da exposição na mídia. A educação em alfabetização midiática tem a intenção de diminuir os impactos negativos da exposição na mídia, na busca por novas evidências que demonstrem os benefícios da alfabetização midiática, encorajando mais educadores a adotarem a prática e a incorporar programas em sala de aula.

As mensagens de mídia representam uma habilidade importante para aprender, principalmente em cenários sociais em que as pessoas não estão previamente educadas para lidar com alterações bruscas da organização cotidiana, como no contexto da pandemia do COVID-19. Nas escolas, a alfabetização midiática pode ser realizada através do desenvolvimento do pensamento crítico e das habilidades de produção de mídia (BURN, DURRAN, 2007, p. 83-87). Como as crianças são apresentadas à publicidade desde o nascimento, sendo chamadas de "Nativos digitais", conforme defende Prensky (2001, p. 01), é importante que pais e escolas ajudem as crianças a entender o que está sendo transmitido e a desenvolver suas próprias opiniões sobre o 
conteúdo (KOTLER et al, 2017, p. 169), especialmente quando estas se encontrem expostas a conteúdos midiáticos por longos períodos.

Ferramentas e ideias para ajudar a informar crianças sobre propagandas podem ser desenvolvidas através da comparação crítica de vídeos e debates, sendo importante que os pais conheçam o que seus filhos mais gostam, discutindo também se o conteúdo audiovisual ou publicitário tem utilidade real ou pode não retratar adequadamente o que está sendo anunciado (OLSON, THJOMOE, 2012, p. 1741). Também pode ser interessante que se discuta sobre a privacidade pessoal, a segurança e a proteção dos dados em linha, evitando convívio com influências negativas, ou que os registros eternos das informações na rede causem constrangimentos futuros, durante a caminhada para a vida adulta.

A mídia ajuda as crianças e adolescentes a entenderem o mundo, embora seja importante para eles entenderem que a mídia pode distorcer imagens e ter significados ocultos, devendo se engajar na interpretação da mídia, em vez de apenas consumi-la, com a consciência de que algumas mensagens são mais complicadas do que parecem (HOLZ, 2017, p. 90).

Assim, escola e família poderão aplicar a disciplina de aprendizagem midiática de modo natural às crianças, através do diálogo e esclarecendo formas mais saudáveis de utilizar as tecnologias de maneira responsável, principalmente no início da formação de futuros cidadãos, os quais precisam desenvolver consciência crítica e maturidade suficiente, capazes de permitir um olhar além do consumo, mas de compreensão dos interesses de mercado, esses tão divorciados dos princípios norteadores do Estado de Direito, os quais devem ser fortalecidos e resguardados desde as suas bases de desenvolvimento, tal como o é no ensino das crianças para o convívio em sociedade e nas relações profissionais de trabalho.

\section{CONSIDERAÇÕES FINAIS}

A convergência de mídia e tecnologia em uma cultura global está mudando a maneira como as pessoas percebem o mundo e desafiando os próprios fundamentos da educação. Não é mais suficiente apenas ler a palavra impressa; de modo que crianças, 
jovens e adultos atualmente precisam da capacidade de interpretar criticamente as poderosas imagens de uma cultura multimídia.

A educação para a alfabetização midiática fornece uma estrutura e uma pedagogia para a nova alfabetização necessária para a vida, o trabalho e a cidadania no século XXI. Além disso, abre o caminho para dominar as habilidades necessárias para a aprendizagem ao longo da vida, em um mundo em constante mudança tecnológica e cultural.

Os desafios de um mundo multimídia podem ser mais facilmente superados quando a alfabetização midiática é inserida desde a infância, dotando as crianças de capacidade crítica, compreensiva e de expressão, de modo a optarem mais conscientemente a respeito das informações que terão contato durante $o$ desenvolvimento como indivíduos, tais como imagens e ideias não apenas da televisão, mas também de sites, filmes, programas de rádio e revistas. capas, e-mail, videogames, música, mensagens de celular, outdoors - e muito mais. Afinal, a linguagem complexa da mídia não mais apenas molda a cultura hodierna, mas é a própria cultura, com suas próprias regras (gramática) e que podem ser usadas para expressar conceitos e ideias de várias camadas sobre o mundo.

Todavia, a expansão das tecnologias digitais e facilitação de acesso às crianças a aparelhos eletrônicos e à rede mundial, através da internet, têm expandido os horizontes do consumo através da publicidade virtual e deliberadamente contribuído para a forma como a população compreende a si na sociedade e absorve informações. Nesse prisma, a fiscalização por parte dos pais é premente, a fim de coibir conteúdo indevido, bombardeamento massivo de anúncios e até mesmo compras não autorizadas, que podem levar a endividamento e publicação de dados particulares em linha.

Desse modo, a pesquisa abordou e contrapôs o consumo infantil em viés multifocal, apresentando dados quantificados, fatos sobre a indústria e o mercado, a psicologia da publicidade e a revisão de legislações e regulamentos voltados para as crianças no Brasil, na busca pela proteção de vulneráveis, de modo que, ao final do trabalho, a aprendizagem midiática volta a ser discutida somente pelo prisma do recorte às crianças, sendo apresentada como alternativa para o consumo consciente e fonte de educação cidadã, frente à utilização de novas tecnologias, no contexto brasileiro, como país de economia marcadamente capitalista, bem como humildemente contribuir com 
informações capazes de fazer o leitor repensar as implicações e responsabilidades da formação de crianças dentro da sociedade de consumo e de mídia.

Ao final, foram apresentadas possibilidades de inserção da disciplina de alfabetização midiática, no contexto da educação à distância, sobretudo em decorrência da pandemia do COVID-19. Muito além da relação pedagógica em sala de aula, a discussão proposta se referiu à inserção de aprendizagem midiática como nova linguagem, na base curricular brasileira, tendo em vista a perspectiva comparada com a realidade educacional de outros países, os quais já estão adaptando os seus sistemas educacionais para formarem cidadãos melhor habilitados frente à manipulação da mídia e à publicidade de fins consumeristas, ao passo que adaptam o sistema tradicional presencial de ensino, a formas desmaterializadas da sala de aula, permitindo que a educação tenha as condições para se manter sempre evoluindo e adaptando, mesmo face a grandes adversidades ou momentos disruptivos para a humanidade.

\section{REFERÊNCIAS}

AN, Soontae. JIN, Hyun Seung; PARK, Eun Hae. Children's Advertising Literacy for Advergames: Perception of the Game as Advertising. Journal of Advertising. Nova York, Routledge, 2014.

BRASIL. Código Civil, Lei 10.406, de 10 de janeiro de 2002. 1a edição. São Paulo: Revista dos Tribunais, 2002.

BRASIL. Constituição da República Federativa do Brasil: promulgada em 5 de outubro de 1988. Brasília: Senado Federal, 1988.

BRASIL. Estatuto da Criança e do Adolescente - ECA, Câmara dos Deputados, Lei no 8.069, de 13 de julho de 1990. DOU de 16/07/1990 - ECA. Brasília, DF.

BRASIL. Lei $\mathbf{n}^{\mathbf{}}$. 8.078, de 11 de setembro de 1990. Código de Defesa do Consumidor. Dispõe sobre a proteção do consumidor e dá outras providências. Disponível em: <http://www.planalto.gov.br/ccivil_03/Leis/L8078.htm>. Acesso em: 10 out. 2018.

BRASIL. Lei $\mathbf{n}^{\circ}$ 12.965, de 23 de abril de 2014. Estabelece princípios, garantias, direitos e deveres para o uso da Internet no Brasil. Brasília. 2014. Disponível em: <http://www.planalto.gov.br/ccivil_03/_ato2011-2014/2014/lei/112965.htm>. Acesso em: 20 out. 2018. 
BRASIL. Superior Tribunal de Justiça. Súmula - STJ. REsp 586.316/MG. Rel. Ministro Herman Benjamin, Segunda Turma, julgado em 17 abr. 2007, DJe 19 mar. 2009.

BOSTROM, Nick. Superintelligence: Paths, Dangers, Strategies. $1^{\text {a }}$ ed. Oxford, RU: Oxford University Press, 2014.328 p.

BOURDIEU, Pierre. Sistemas de ensino e sistemas de pensamento. In: MICELLI, S. (Org.). A economia das trocas simbólicas. São Paulo: Perspectiva, 1992, p. 203-229.

BOURDIEU, Pierre. Escritos de educação. 2. ed. Petrópolis: Vozes, 1998.

BUCKINGHAM, David. As crianças e a mídia: uma abordagem sob a ótica dos Estudos Culturais. Matrizes, vol. 5, núm. 2, pp. 93-121. Universidade de São Paulo. São Paulo, Brasil, 2002. Publicado originalmente em Handbook of Children, Media and Culture, de Kirsten Drotner e Sonia Livingstone (eds.) Londres: Sage, 2008.

BURN, Andrew. DURRAN, James Media Literacy in Schools. London: Sage Publisher, 2007.

CENTER FOR MEDIA LITERACY - CML. The Voices of Media Literacy Interviews of Neil Andersen (Canada); Cary Bazalgette (UK); David Buckingham (UK); Marilyn Cohen (U.S.); David Considine (U.S. by way of Australia); Barry Duncan (Canada); Lesley Farmer (U.S.); Jean Pierre Golay (U.S. by way of Switzerland); Renee Hobbs (U.S.); Douglas Kellner (U.S.); Robert Kubey (U.S.); Len Masterman (UK); Barrie McMahon (Australia); Kate Moody (U.S.); Renee CherowO'Leary (U.S.); James Potter (U.S.); Robyn Quin (Australia); Marieli Rowe (U.S. by way of Switzerland); Dorothy G. Singer (U.S.); Victor Strasburger, MD (US); Elizabeth Thoman (U.S.); Kathleen Tyner (U.S.); Chris Worsnop (Canada), 2018. Disponível em: <http://www.medialit.org/voices-media-literacy-international-pioneers-speak>. Acesso em: 20 dez. 2018.

CENTRO REGIONAL DE ESTUDOS PARA O DESENVOLVIMENTO DA SOCIEDADE DA INFORMAÇÃO - CETIC. Tic Kids Online Brasil - 2017. Versão online. Disponível em:< https://cetic.br/pesquisa/kids-online/>. Acesso em: 15 nov. 2018 .

CONAR. Código Brasileiro de Autorregulamentação Publicitária. São Paulo. 1980. Disponível em: <http://www.conar.org.br/codigo/codigo.php>. Acesso em: 30 out. 2018.

CORRÊA, Luciana. Children and Internet use: A comparative analysis of Brazil and seven European countries. ESPM Publicação online: Media LAB, 2016. Disponível em: <http://info.abril.com.br/noticias/internet/2014/07/youtube-afirma-que-brasileiros-saomaiores-consumidores-de-videos-no-portal.shtml>. Data de acesso: 15 nov. 2018.

ENZENSBERGER, Hans Magnus. Elementos para uma Teoria dos Meios de Comunicação. São Paulo: Conrad, 2003. 
EUROPEAN AUDIOVISUAL OBSERVATORY - EAO. Mapping of media literacy practices and actions in EU-28. Strasbourg: European Audiovisual Observatory, 2016. Disponível em: <https://www.medieraadet.dk/files/docs/201802/Media\%20literacy\%20mapping\%20report\%20-\%20EN\%20-\%20FINAL.pdf.pdf >. Acesso em: 25 dez. 2018.

GAPSKI, Harald. Medienkompetenz. Eine Bestandsaufnahme und Vorüberlegungen zu einem systemtheoretischen Rahmenkonzept. Wiesbaden: Springer Verlag, 2001.

GUNTER, Barrie. Kids and branding in a digital world. Manchester: Manchester University Press, 2015.

HABERMAS, Jürgen. Dialética e Hermenêutica - para a crítica da hermenêutica de Gadamer. Porto Alegre: L\&PM, 1987.

Teoria de la acción comunicativa I - Racionalidad de la acción y racionalización social. Madri: Taurus, 1987.

. Teoria de la acción comunicativa II - Crítica de la razón funcionalista. Madri: Taurus, 1987.

HOFFMANN, Bernward. Medienpädagogik. Eine Einführung in die Theorie und Praxis. Paderborn: Ferdinand Schöningh, 2003.

HOLZ, Jo (2017). Kids' TV Grows Up: The Path from Howdy Doody to SpongeBob. Jefferson: McFarland, 2017.

HÜBNER, Edwin: Medien und Pädagogik. Gesichtspunkte zum Verständnis der Medien, Grundlagen einer anthroposophisch- anthropologischen Medienpädagogik. Stuttgart: Pädagogische Forschungsstelle beim Bund der Freien Waldorfschulen Verlag, 2015.

KOTLER, Philip. KARTAJAYA, Hermawan. SETIAWAN, Iwan. Marketing 4.0: Moving from Traditional to Digital. Hoboken, Wiley Editors, 2017.

KUNKEL, Dale. WILCOX; Brian. PALMER, Edward Palmer. CANTOR, Joanne. DOWRICK, Peter. LINN, Susan Linn. Report of the APA Task Force on Advertising and Children. Washington: The American Psychological Association, 2004. Disponível em: <https://www.apa.org/pi/families/resources/advertising-children.pdf>. Acesso em: 15 nov. 2018.

LORENZETTI, Ricardo Luis. Comércio eletrônico. Trad. de Fabiano Menke. São Paulo: Ed. RT, 2004.

MARQUES, Claudia Lima. A nova crise do contrato: estudos sobre a nova teoria contratual. São Paulo: Ed. RT, 2007. 
MCNEAL, James U. Kids as Customers: A Handbook of Marketing to Children. Nova York: Lexington Books, 1992.

NASCIMENTO, I. P. As representações sociais do projeto de vida dos adolescentes: um estudo psicossocial. 380 f. Tese (Doutorado em Educação) - Programa de PósGraduação em Psicologia da Educação, Pontifícia Universidade Católica de São Paulo, São Paulo (2002).

NICHOLLS, Alexander James Nicholls. CULLEN, Peter. The child-parent purchase relationship: 'pester power', human rights and retail ethics. Amsterdam: Journal of Retailing and Consumer Services - Elsevier, 2004. p 75-86.

OLSON, Erik L. THJØMØE, Hans Mathias. The relative performance of TV sponsorship versus television spot advertising. Bingley: European Journal of Marketing, 2012. p. 1726-1742.

ORGANIZAÇÃO DAS NAÇÕES UNIDAS PARA A EDUCAÇÃO, A CIÊNCIA E A Cultura - UNESCO. Early childhood care and education. Disponível em: $<$ https://en.unesco.org/themes/early-childhood-care-and-education>. Acesso em 20 nov. 2018.

POTTER, James W. Introduction to Media Literacy. Londres: Sage Publisher, 2016. $296 \mathrm{p}$.

POTTER, James W. Theory of Media Literacy: A Cognitive Approach. Londres: Sage Publisher, 2004.

PUGH, Allison J. Longing and Belonging: Parents, Children and Consumer Culture. Berkeley: University of California Press, 2009.

REIHER, Robert H. ACUFF, Daniel. What Kids Buy: The Psychology of Marketing to Kids. Nova Iorque: Free Press, 2008. 218 p.

SAMMOND, Nicholas. Babes in Tomorrowland: Walt Disney and the Making of the American Child, 1930-1960. Durham, NC: Duke University Press, 2005.

SCHOR, Juliet B. Born to Buy: The Commercialized Child and the New Consumer Culture. New York: Scribner, 2004.

SERVIÇO DE PROTEÇÃO AO CRÉDITO - SPC BRASIL. Consumo Infantil. Disponível em: <https://www.spcbrasil.org.br/uploads/st_imprensa/analise_consumo_infantil_setembro _20151.pdf>. Acesso em: 25 nov. 2018.

SOZIO, Maria Eugenia. PONTE, Cristina. SAMPAIO, Inês Vitorino. SENNE, Fabio. OLÁFSSON, Kjartan. ALVES, Suzana Jaíze. GARROUX, Camila. Children and Internet use: A comparative analysis of Brazil and seven European countries. Genebra: EU Kids Online, 2015. Disponível em: 
<https://www.cetic.br/media/docs/publicacoes/5/Children\%20and\%20Internet\%20use.p df $>$. Acesso em: 20 nov. 2018.

TURNER, Graeme. The Media and Communications in Australia. 3 ed. Crows Nest: Allen \& Unwin, 2010.

UNITED NATIONS EDUCATIONAL, SCIENTIFIC AND CULTURAL ORGANIZATION - UNESCO. Global Media and Information Literacy (MIL) Assessment Framework: Conutry Readiness and Competencies. Paris:UNESCO, 2013. Disponível em: <https://unesdoc.unesco.org/ark:/48223/pf0000224655>. Acesso em: 22 dez. 2018.

VALKENBURG, Patti M.; CANTOR, Joanne. The development of a child into a consumer. Amsterdam: Journal of Applied Developmental Psychology - Elsevier, 2001.

VOLLBRECHT, Ralph. Einführung in die Medienpädagogik. Weinheim: Beltz Verlag, 2001.

WALLIS, Richard; BUCKINGHAM, David (2013-10-01). Arming the citizenconsumer: The invention of 'media literacy' within UK communications policy. Londres: Revista Europeia de Comunicação, vol. 28, p. 527-540, 2013. Disponível em:<https://journals.sagepub.com/doi/abs/10.1177/0267323113483605?journalCode=ej ca>. Acesso em: 28 dez. 2018. 